\title{
Functions of Code Switching in Schoolchildren's Conversations
}

\author{
Iliana Reyes \\ University of Arizona
}

\begin{abstract}
This study examined the code-switching patterns in the speech of immigrant Spanish-speaking children. Seven- and 10-year-old boys and girls from bilingual classrooms were each paired with a mutually selected friend, and their speech was collected in two contexts: while the children waited for an expected science experiment and when they worked together to follow an instruction worksheet about hands-on magnetic materials. This study presents data on the discourse characteristics of children's code switching, and the functions that Spanish and English have according to context. In addition, the data are described in relation to children's language competence and preference. The study found that code switching occurred both within and across turns. The older children's switches were more frequent and were deployed for a wider variety of functions than the younger children's. The results challenge the negative view that code switching by children who are learning two languages is due to lack of proficiency, and instead support the view that it is used as a strategy to extend their communicative competence during peer interaction.
\end{abstract}

\section{Introduction}

Conversation constitutes a major part of human interaction. It is through language and conversation that children begin to communicate information through a variety of speech registers and style switching (Ervin-Tripp, 2001). Of particular interest to sociolinguistic and developmental researchers is the impressive ability of bilingual speakers to switch with ease at different points in conversation. From the sociolinguist's point of view, code switching (CS) is studied to understand why people who are competent in two languages alternate languages in a particular conversation or situation. The concept of 
CS, as defined by Gumperz (1973), refers to the alternate use of two or more languages in the same utterance or conversation.

Most of the early research on CS has looked at adult-adult interaction (e.g., Clyne, 1967; Gumperz, 1967, 1973; Weinreich, 1953). However, the early 1980s witnessed increased interest in studying children's CS (Álvarez, 1979; Genishi, 1976; Zentella, 1982, 1997). These studies have shed some light on how bilingual children use different languages according to addressee and context. However, these studies do not describe how children develop CS over the years, and how CS is used to extend communicative competence for achieving conversational goals during peer interaction. In the classic CS study by Poplack (1980) with Puerto Rican American bilinguals, she analyzed adults' conversations in natural settings and speech during a sociolinguistic interview to learn about bilinguals' linguistic competence and their use of CS. Poplack's findings pointed out that CS was used by those individuals whose language skills in both languages were balanced. While CS might be an indicator of bilingual ability in adults (Poplack, 1980), it might indicate development of bilingual communicative competence in children who are still learning a second language (L2) (Reyes, 2001).

The present study analyzed the functions of CS in the speech of peers, for the primary purpose of exploring the relation between CS functions and development of children's bilingual communicative competence. In this study, communicative competence refers to the speaker's knowledge of when to speak and when not to, and what to talk about with whom, when, where, and in what manner (Hymes, 1974). Based on previous research, we know that monolingual speakers have the capacity to switch between a variety of linguistic registers (e.g., Gumperz, 1967; Ervin-Tripp, 1964, 2001). Similarly, bilinguals also have these communicative registers that monolinguals have, but in addition they have two linguistic codes that they can alternate as a resource for sociolinguistic strategies during conversation.

\section{Literature Review: Code Switching in Children}

Early research in this area has identified the types of CS and the factors affecting it (e.g., Clyne, 1967; Ervin-Tripp, 1964; Fishman, 1965; Gumperz, 1964, 1967; Gumperz \& Hernández-Chavez, 1975). More specifically, CS varies according to the situation (situational code switching) and within a conversation (metaphorical code switching). Under the metaphorical category, CS varies according to discourse function (e.g., to include or exclude someone from a conversation, to convey intimacy, or to emphasize a message).

Research on children's CS has shown that simultaneous bilinguals develop knowledge on how and when to use their two languages depending on the addressee, the topic of the conversation, and the situation (Fantini, 1985; Genishi, 1976; Halmari \& Smith, 1994; McClure, 1981; Zentella, 1982, 1997). 
More recently, Genesee and his colleagues (Genesee, 2002; Genesee, Boivin, \& Nicoladis, 1996) have found that French-English bilinguals as young as 2 years of age develop the ability to use and adjust each of their languages differentially and appropriately with parents and an unfamiliar interlocutor as part of their communicative competence. Genesee (2002) goes further to state that "true bilingual communicative competence entails the ability to adapt one's language use on-line in accordance with relevant characteristics of the situation, including the preferred or more proficient language of one's interlocutor" (p. 174).

Scientific evidence from studies with young Spanish-English bilinguals (McClure, 1981; Zentella, 1997) report that younger children show more lexicalitem CS than older children. A common assumption to explain this finding is that children code switch when they do not know the word in one language. Hence, they draw on the other language. It is incorrect, however, to assume that all cases of this type of code switch are the result of incomplete knowledge of one of the languages. In some cases, children might be momentarily unable to access a word for a concept in the language in use, but can access one more readily in the other language. On the other hand, older children seem to manipulate their linguistic codes for a wider variety of stylistic purposes and situational demands than younger children do (Zentella, 1997). In a study with peer Turkish-Danish bilinguals, Jørgensen (1998) found that 7- to 10year-olds could manipulate their two languages for power-wielding purposes. The children in his study strove to gain control of the conversation when involved in problem-solving tasks. Research findings also indicate that older children code switch when they learn that elements of the other language convey the meaning of the intended idea more accurately (Halmari \& Smith, 1994; Zentella, 1997). However, we do not know well how "developing bilingual children" develop the ability to code switch over the years and how they make use of this strategy during peer interaction.

\section{Theoretical Framework}

This study was guided by a number of theoretical assumptions related to bilingualism and communicative competence. First, in terms of children's use of CS, it was expected that older children would use code switches at a higher rate and for a greater range of sociolinguistic functions than younger children. This expectation is based on the assumption that older children would have developed a higher level of proficiency in their L2 and greater knowledge of the grammatical systems of both their first and second languages-factors that have been found necessary for CS (Poplack, 1980). In addition, other studies report that as children get older, they develop and use more sophisticated discourse strategies (e.g., Ervin-Tripp \& Mitchell-Kernan, 1977). The nature of language development in these developing bilinguals must be understood in relation to their development of bilingual communicative competence (Genesee, 2002; Reyes, 2001). In other words, as bilingual children 
become older, their exposure to different social and linguistic experiences increases, and these experiences in turn affect and enlarge their knowledge and ability to use their different languages and to deploy CS for sociolinguistic purposes. Second, children's patterns of using language and CS often mirror the ways in which language is used in their communities (Lanza, 1997; Schieffelin \& Ochs, 1986). In addition, research by Poplack (1980) with adults and by Zentella $(1982,1997)$ with children indicate that those speakers who are more fluent and balanced in both languages tend to be better at alternating and switching languages. Based on these previous findings, a relation between CS and the number of years children have been exposed to their L2 was expected. The working hypothesis from a developmental perspective is that $\mathrm{CS}$ increases in bilingual children as they have more exposure to the L2, and it is used as a resource to extend communicative competence. A sociolinguistic theory of CS acquisition by bilingual children is necessary to understand the development of communicative competence when learning an $\mathrm{L} 2$ and becoming bilingual.

The focus in this article is to investigate how schoolchildren from two age groups (7- and 10-year-olds) switch between two different languages, English and Spanish, and draw on features of each language to accomplish their conversational goals. In particular, peer interaction without an adult present was analyzed to explore how children make use of their native language (Spanish) and their L2 (English) in a social and school-related context. The research questions were as follows:

1. How do children use CS during peer interactions?

2. What are the sociolinguistic functions of the code switches used by school-age children from different age groups?

3. Is there an effect of context on the type of CS and language used by schoolchildren (e.g., social setting vs. school-related setting)?

\section{Methodology}

Participants

\section{Demographics}

A total of 20 self-selected friend dyads participated in this study. These children were in second- and fifth-grade classrooms in an elementary school in Oakland, California. Ten dyads from each grade were recruited. Most of the children were of Mexican background, with the exception of two, who were Central Americans. The mean ages of the children were 10 years, 8 months and 7 years, 9 months for the fifth and second graders, respectively. Children were given a small gift (e.g., stickers and pencils) for their participation.

The school where this study took place is part of a working-class Latino and African American neighborhood. The children learned and continue to use Spanish at home but hear and learn English in school and the community around them (Reyes, 2001). These children participate in a transitional bilingual 
program, but the school is not bilingual. In general, teachers supported the use and development of both Spanish and English. Teachers and children used both languages outside the classroom as well as during classroom interaction.

\section{Language background}

Information regarding each child's language background was obtained from the parents and the teachers. The parents reported the language they thought their child spoke the best, and they gave information about the age at which the child learned English. The teachers were asked the same questions; in addition, teachers used school test scores to report on each child's language proficiency. In a brief interview, the children were asked about their language preference at home with parents and siblings, as well as in school with teachers, staff, and friends.

The parents' and teachers' reports were compared for agreement. In most cases, parents and teachers agreed about the relative proficiency of the children. However, in those cases where their reports did not agree, we looked at the students' school English placement scores to determine their relative fluency in English. In the few cases in which parents and teachers disagreed, the parents underestimated the children's fluency in English. This could be explained by the fact that most of the parents see their children in a monolingual Spanish environment. In contrast, teachers see the children at school, where children are learning English and speak both languages throughout the day. Children's relative language knowledge was determined for each language by looking at the information about each child's language abilities as observed by the parents, teachers, and researchers. Table 1 shows students' relative proficiency in each language and their language preference (data for all children are included, except for two who were absent the day of the interview).

Table 1

Children's Language Background: Proficiency and Preference by Age Group

\begin{tabular}{|l|r|r|r|r|}
\hline & \multicolumn{2}{|l|}{ Students' language proficiency } & \multicolumn{2}{l|}{ Students' language preference } \\
\hline & 7 -year-olds & 10 -year-olds & 7-year-olds & 10 -year-olds \\
\hline Spanish & $69 \%$ & $25 \%$ & $33 \%$ & $20 \%$ \\
\hline English & $6 \%$ & $12 \%$ & $47 \%$ & $47 \%$ \\
\hline Both & $25 \%$ & $63 \%$ & $20 \%$ & $33 \%$ \\
\hline
\end{tabular}


The results in Table 1 show that on average, the younger children were mostly dominant in Spanish (69\%), followed by $25 \%$ who were considered balanced in both languages, and only $6 \%$ were considered English dominant. By contrast, we see that on average, $63 \%$ of the older children were considered balanced bilinguals (at least at the oral level). A very different picture emerged when we looked at language preference reported by the children. A total of $47 \%$ of the younger children reported that they preferred to speak English, $33 \%$ preferred Spanish, and 20\% said that they had no preference. For the older children, a similar pattern was observed, with a $47 \%$ preference for English. However, for Spanish preference and absence of preference, there was an inverse pattern: $33 \%$ of 10 -year-olds had no language preference, while only $20 \%$ reported that they preferred to speak Spanish. The language preference pattern contradicts data regarding younger children's relative proficiency. While nearly $50 \%$ of the children in each group said they preferred English, only $25 \%$ of the younger children were considered proficient in both English and Spanish. Regardless of their language proficiency, children from a young age already can grasp the dominant perception that English is the language of higher prestige in U.S. society.

\section{Design and Procedure}

About 10 hours of conversations were audiotaped over a period of 8 weeks during the children's lunch break. Participants were told that the researchers were interested in children's conversations during a science project and that they would be participating in a science activity. The children were asked to nominate a friend with whom they wanted to participate in the science activity.

Each dyad participated in one session. First, children were taken to the cafeteria to eat lunch, and after that they were taken to the music room in the school's auditorium to be tested. The children's conversations were recorded as soon as the microphones were put on them. They were instructed to have a seat and just talk while they waited for the two researchers to prepare the science activity. Both researchers present were bilingual and gave instructions to the children, alternating between English and Spanish. The researchers left the room, and they monitored and recorded the children's conversation from an adjacent room. After 15 minutes, the researchers returned and explained the science activity to the children, alternating between English and Spanish. The researchers code switched among themselves and to the children, in order to set the stage for CS. This way, the researchers modeled CS to let the children know that it was acceptable to speak both languages. Various researchers (e.g., Bayley \& Zapata, 1993; Zentella, 1997) have noted that, historically, there has been a pejorative connotation to "Spanglish" and CS. To avoid negative perceptions that some children might have had about CS, it was important to let them to know that CS was valued as a discourse style by 
the researcher and student assistants in the project. After another 15 minutes, the researchers returned and inquired about the dyad's science findings.

\section{Materials}

A wireless microphone was connected to a transmitter inside a belt pack that was strapped to each child's waist, each with a different radio frequency. Each microphone was clipped to the child's shirt. Radio receivers and a cassette recorder were set up outside the room where the study was being conducted in order to receive and record the children's conversations on separate channels for each voice.

The materials used for the science activity included a compartmented box, with labels in both languages and containing magnets of different forms and colors, a compass, various magnetic rocks, and miscellaneous metal and nonmetallic objects (e.g., paper clips, thumbtacks, keys), and a clear plastic box containing iron filings. A worksheet had eight questions, in both English and Spanish, regarding the items in the box and how they interacted with one another (see Appendix A). This worksheet was used to prompt conversation regarding the science activity and minimize silent play. Children had the option of discussing the questions in English or Spanish.

\section{Data Analysis}

The conversations were transcribed for analysis using Gumperz and Berenz's (1993) transcription conventions (see Appendix B). Each of the conversations lasted about 30 minutes. Each speaker's turn, between the turns of speaking by the other child, was taken as a unit of analysis. For the frequency analysis, counts of all code switches were made at two levels. First, all the code switches from English to Spanish and Spanish to English were counted. Second, the number of turns per conversational dyad and per language were computed separately for each setting: the social-talk context and task-related conversation within the science activity. During the analysis, it was determined that some of the talk in the science setting was off task and social in nature (e.g., children talked about their favorite television show while answering the science questions). This intermittent social talk within the science activity was analyzed separately. For comparison purposes, proportions were computed by dividing the number of code switches by the number of turns for each child to yield a measure of CS probability per turn in each context.

For the sociolinguistic analysis, coders were trained to use a specific coding frame. It is important to clarify that only code switches that constitute more than one lexical item were included in the analysis. Many investigators in the field of language CS do not consider single switches (also called borrowings or tag switches) "true switches," therefore, only those longer switches that clearly indicated a syntactic switch into the other language 
have been included in the present analysis (see Romaine, 1995, for further discussion on this issue). The following examples illustrate these two types of code switches ${ }^{1}$ (see Appendix B for transcription annotations):

Example 1: e: se agarran asi ira shake your booty

t: they do it like this look

In the next example, the word lonchera illustrates a one-word switch or lexical item. Overall, this type of one-word switch has been phonologically assimilated into the speech community, and often it will be used in the speech of monolingual speakers as well.

Example 2: e: i'm going to the classroom to get my lonchera t: lunch box

The code switches were analyzed in terms of content and function in relation to location in the conversation. To determine the extent of use of each language, the total number of turns in only English or only Spanish, and in both English and Spanish, were counted separately. The following are the three categories used to code each child's turns:

1. Spanish only: All phrases in one turn were Spanish, with no CS to English.

2. English only: All phrases in one turn were English, with no CS to Spanish.

3. Mixed language: Both languages were used within the same turn (one word or more).

For the analysis of conversational functions, the different types of code switches that were most prevalent in the children's conversations were first identified through analysis of the transcripts and then compared with the CS typologies used in previous frameworks by Gumperz (1967), McClure (1981), and Zentella (1997). In the end, combining new data-based and older typologies facilitated identification of the categories most relevant to the code switches produced by the children in this study. The study used 12 categories in the analysis for conversational CS. These categories were used to indicate the conversational function of the code switch and were always determined in relation to the contextual information at a specific point of the ongoing conversation. ${ }^{2}$

1. Representation of speech: CS employed to represent talk. t: all right I'm calm I'm calm ... a lo major están diciendo estan chulos e: $\quad \quad$... may be they are saying that we are good looking

2. Imitation quotation: CS involving imitation and change in tone of voice to play a particular character.

t: $y$ luego le hace si $\quad$ [robot voice] i'm hungry\}

e: and then he says yes

3. Turn accommodation: CS occurring between speakers' turns.

Claudia: t: y luego se va salir a las cuatro y media from school 
e: and then she's getting out at four thirty from school

Jimena: t: de la project school?

e: from the school project?

Claudia: t: summer school she don't need to go to summer school

4. Topic shift: CS occurring due to a change of topic in conversation.

$\mathrm{t}$ : we finished all the books ... thank you mira mis calzones se me andan cayendo

e:

... look at my underwear they are falling

5. Situation switch (on/off topic in academic work): CS marking a switch between science talk and non-science talk.

$\mathrm{t}$ : mira mira los magnets ... what was he saying during recess

e: look look the magnets

6. Insistence (non-command): CS indicating a child's persistence in a specific idea. The child usually repeated the same utterance in both languages.

$\mathrm{t}$ : a ver... let me see

e: let me see...

7. Emphasis (command): CS used to put emphasis on a specific command.

t: loud leelo loud!

e: loud read it loud!

8. Clarification or persuasion: CS giving more information to clarify an idea or message.

$\mathrm{t}$ : andale pues esa cosa we don't need this no more

e: yeah that thing

9. Person specification: CS occurring when children referred to another person during their conversation.

t: you should ask A\#given name\# si quiere comer nieve después de la escuela

e:

if she wants to eat ice cream after school

10. Question shift: CS indicating a switch in language when children had a question.

t: let me see cómo le hiciste?

e: how did you do it?

11. Discourse marker: Discourse markers are linguistic elements that do not necessarily add to the content of the utterance but act as markers of the context in which the utterance is taking place (Escalera, 2002).

t: okay asi ira

e: like this look

12. Other: This last category was used to code instances in which the function of the CS could not be identified.

t: a mi me gusta big teeth

e: i like 


\section{Results}

Language Use

During the social talk, both the 7-year-olds and 10-year-olds used more Spanish than English. This finding was expected, considering the children's linguistic proficiency in Spanish and English. Unexpectedly, a similar pattern was observed for language use during the science activity. Developmentally, it was anticipated that the 7-year-old children would use their native language (Spanish) with a higher frequency than the 10-year-olds because the latter have developed higher degrees of bilingual proficiency. Table 2 shows the frequency for each language used by age group across the two contexts: the social setting and the science activity setting. ${ }^{3}$

As can be seen in Table 2, on average, the 7-year-olds used Spanish in $81 \%$ of their total conversational turns in the social setting and used English for only $7 \%$ of their conversational turns in that segment. For the 10-yearolds, there was a decrease in the use of Spanish, hence an increase in English, as well as a decrease in code-switched turns. Both groups of children used their native language, Spanish, as the base language during their conversations. However, we see that the 10-year-olds used English and mixed English and Spanish in about 33\% of their turns, in comparison with the 7year-olds, who only used English and mixed English and Spanish for about $19 \%$ of their turns.

Table 2

Average Percentage Distribution of Total Conversational Turns by Language Choice

\begin{tabular}{|l|r|r|r|}
\hline \multicolumn{4}{|c|}{ Context-language choice in social talk } \\
\hline \multicolumn{1}{|c|}{ Participants } & \multicolumn{1}{|c|}{ Spanish } & \multicolumn{1}{c|}{ English } & \multicolumn{1}{c|}{ Both } \\
\hline 7-year-olds & $81 \%$ & $7 \%$ & $12 \%$ \\
\hline 10-year-olds & $67 \%$ & $17 \%$ & $16 \%$ \\
\hline Language choice in science activity (on-task and off-task talk included) \\
\hline 7-year-olds & $77 \%$ & $9 \%$ & $14 \%$ \\
\hline 10-year-olds & $68 \%$ & $15 \%$ & $17 \%$ \\
\hline
\end{tabular}

During the science activity, surprisingly, both age groups used Spanish again as the base language. The 7-year-olds used Spanish for more than $75 \%$ of their total turns during the science activity. Hence, the 7-year-olds showed a slight increase in use of English during the science activity, compared with the social setting, but they still used Spanish as the primary language for 
discussing social and academic topics during peer interaction. The 10-yearold children showed a similar pattern of language use in both contexts (social talk and on-task science talk).

\section{Code Switching}

The results indicate that the younger children code switched less than the older children. The 7-year-old children used Spanish as the base language during the social talk, code switched to English, and then code switched back to their base language. The 10-year-old children code switched with greater frequency than the younger children (see Table 3). Furthermore, the analysis reveals that on average, the 7-year-olds used three types of CS, in comparison with the 10-year-olds, who used an average of five types of CS during their conversations. Older children seemed to use a wider range of CS to fulfill different sociolinguistic functions. This finding seems to indicate a relationship between the number of years children have been exposed to their L2 and the influence on their bilingual communicative skills.

\section{Code-Switching Frequency}

A comparison of CS during the two contexts-social talk and the science activity (on-task talk) - found that 7-year-olds showed a similar pattern in the frequency of code switches across contexts: an average of $13 \%$ and $10 \%$ for social talk and science activity (on-task talk), respectively (see Table 3). Only a small decrease (3\%) of code switches was observed in looking at social talk as opposed to science talk for the 7-year-old children. An identical pattern was observed for the 10-year-old children in the social talk and science activity (on-task talk) contexts. The average frequency of code switches in their conversational turns-in both contexts-was about $28 \%$.

Table 3

Average Percentage of Turns With Code Switches Used by Children in Different Contexts

\begin{tabular}{|l|r|r|}
\hline Age group & Social talk & $\begin{array}{c}\text { Science activity } \\
\text { (on-task talk) }\end{array}$ \\
\hline 7-year-olds & $13 \%$ & $10 \%$ \\
\hline 10-year-olds & $28 \%$ & $28 \%$ \\
\hline
\end{tabular}

The results indicate that 10-year-old children code switched significantly more in all contexts when compared to 7-year-old children. An analysis of variance (ANOVA) with age as the between-subjects variable and context as the within-subjects variable confirmed these important findings. First, the difference in frequency of CS between the two age groups was statistically significant $(F[1,31]=11.80, p<.01)$, showing a higher frequency of CS by the 
older children (10-year-olds). However, the difference in frequency of CS according to context was not significant. That is, both groups of children code switched with the same frequency during the social context as they did during the science activity context.

In addition, an analysis was done to determine if there was a relation between the frequency of CS and the number of years a child had been exposed to the L2. In order to determine if these two variables were correlated, the researcher assigned the 10-year-old children to two different groups. The first group included those children who had been exposed to English (the L2) for 2 years or less. In the second group, only those children who had been exposed to the $\mathrm{L} 2$ for at least 3 years were included. The percentage of conversational turns in which the two groups of children code switched is illustrated in Figure 1.

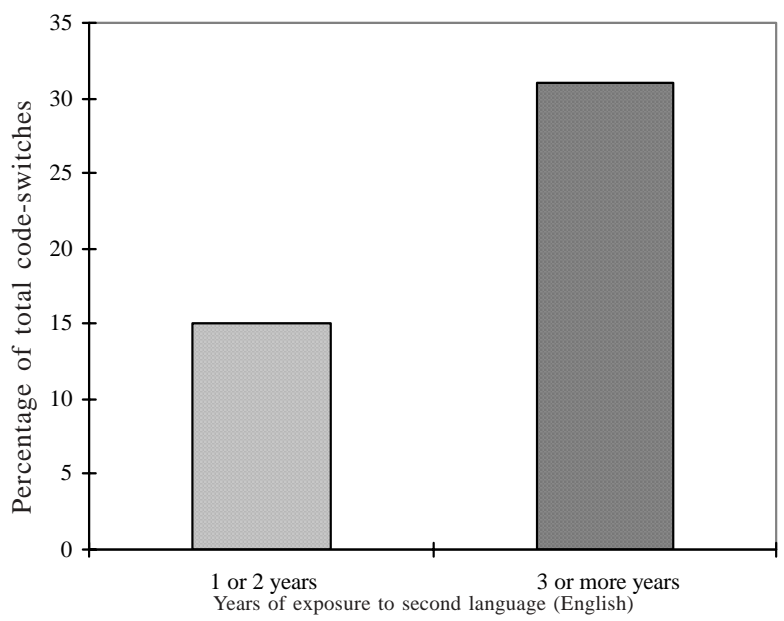

Figure 1. Percentage of 10-year-olds' conversational turns that used code switching, by number of years exposed to English.

The 10-year-old children who had been exposed to English for 3 or more years code switched in $33 \%$ of their total conversational turns, in comparison with the 10-year-olds who had been exposed to English for 1 to 2 years, who only code switched in $15 \%$ of their total turns. This result shows a trend in the relationship between the number of years children have been exposed to an L2 and the frequency and use of CS in their conversations (this will be further addressed in the Discussion and Conclusion section).

\section{Code-Switching Functions}

For the sociolinguistic analysis, children showed variation in the types of CS functions they used according to context. A summary of the most commonly used types of CS by age group is given in Table 4 . 
Table 4

Sociolinguistic Functions of Code Switches by Activity, in Order of Frequency

\begin{tabular}{|c|l|l|l|}
\hline Age group & \multicolumn{1}{|c|}{ Social talk } & \multicolumn{1}{|c|}{$\begin{array}{c}\text { Science activity } \\
\text { on-ask talk }\end{array}$} & \multicolumn{1}{|c|}{$\begin{array}{c}\text { Science activity } \\
\text { off-task talk }\end{array}$} \\
\hline 7-year-olds & $\begin{array}{l}\text { 1. Topic shift } \\
\text { 2. Emphasis } \\
\text { 3. Clarification }\end{array}$ & $\begin{array}{l}\text { 1. Clarifcation } \\
\text { 2. Emphasis } \\
\text { 3. Question shift }\end{array}$ & $\begin{array}{l}\text { 1. Situation switch } \\
\text { 2. Topic shift } \\
\text { 3. Emphasis }\end{array}$ \\
\hline 10-year-olds & $\begin{array}{l}\text { 1. Topic shift } \\
\text { 2. Clarification } \\
\text { 3. Accommodation }\end{array}$ & $\begin{array}{l}\text { 1. Clarification } \\
\text { 2. Topic shift } \\
\text { 3. Question shift }\end{array}$ & $\begin{array}{l}\text { 1. Situation switch } \\
\text { 2. Topic shift } \\
\text { 3. Accommodation }\end{array}$ \\
\hline
\end{tabular}

Across age groups, for the social context, the four most commonly used types of functions were topic shift, clarification, emphasis, and turn accommodation. The topic shift type of code switch was the most frequently used by both groups of children during the social setting (24\% of total code switches among 7-year-olds and $19 \%$ of switches among 10-year-olds). Children frequently code switched while changing topics. This type of CS function seems to be particularly important in social talk, because children spent a great deal of time talking about social events and teasing each other (see example below):

Fernando: t: ira lo que voy hacer

e: look what i'm going to do\#child is playing with Play-Doh\#

Cesar: $\quad \mathrm{t}:$ que son? son Power Rangers?

e: what are they? are they Power Rangers?

t: go go Power Ranger... man, is this the activity? es la migra blood

e:

they are the immigration

\#child is referring to researchers as immigration officers\#

[both children laugh]

In this example, we see how Fernando and Cesar, 10-year-old boys, switch languages from Spanish to English when talking about popular characters (Power Rangers) in a television show, but switch back to Spanish when changing topics to refer to "immigration officers." These children were teasing each other while code switching to Spanish to refer to the researchers (who were in the next room) as the migra [immigration officers]. This particular dyad continues to code switch throughout the conversation in both the social and science activity contexts. 
The second most used category by the young children was emphasis, followed by clarification. For the 10-year-olds, clarification was the second most used sociolinguistic function, followed by turn accommodation. Specifically, older children accommodated their speech by CS according to their peers' linguistic knowledge, a strategy that draws from implicit metalinguistic knowledge ${ }^{4}$ to monitor speech. These findings showed that older children, who have developed bilingual communicate competence, were aware of their listeners' linguistic abilities, as exemplified in the following conversation of two fifth graders:

Alberto: $\quad$ t: hay *vas mas o menos con el *inglés

e: you're getting english more or less

Francisco: t: yo invento ${ }^{*} \cos a s$ /

e: $i$ invent things

Alberto: t: *eh?

e: 'huh?'

Francisco: t: *yo invento *cosas/

e: $i$ invent things

Alberto: t: pero *porque buey?

e: but why dude?

Francisco: t: *asi como el *inglés

e: like in english

t: le *hace...le hace mi *hermana..l-..(es)tá...-ta todavia

-ta * chiquita y le hace...lo *hacel

e: she goes...my sister goes..1-..my sister goes 1-...she's she's still she's small and she goes ... like this'

Francisco: $t:\{[$ with a deep Spanish accent] oh tu espeak

*espanish..*no/

no *inglish..no *comprende $\} /$

e: oh you speak Spanish...no...no english..you don't

understand

t: she say oh you speak spanish no.. no english..don't

understand

e: she (says) oh you speak Spanish ... no ... you don't

understand english

Alberto: t: oh/ good/

In the example above, Alberto (bilingual) and Francisco (Spanish dominant) are talking about how Francisco is getting better at speaking English. Alberto refrained from CS and carried out a conversation with Francisco mostly 
in Spanish. In this example, we also observed one of the two code switches produced by Francisco during their conversation. This example supports the claim that those children who can code switch to accommodate peers during interaction demonstrate higher bilingual communicative skills.

During the science activity (on-task talk), the four most common types of code switches used across age groups were clarification, emphasis, topic shift, and question shift. In terms of code-switch variation during the science activity, the only difference across age groups was the use of the emphasis type of CS for the young children and the topic shift type of CS for the older children. The pattern of code switches children used during the science activity when they were off task is more similar to that of the social-talk context. The 7year-olds used situation switch, topic shift, and emphasis more frequently than any other type of CS. In a similar way, 10-year-olds used situation switch, topic shift, and accommodation shift within their conversations.

This slight variation in the type of code switches observed across age groups suggests a developmental trait. For example, the use of the emphasis type of CS by the 7-year-olds during the science activity (on-task talk) reflects the use of more commands, hence, more command-related emphasis through CS among 7-year-olds to get through the science activity questions. This finding corroborates with Jørgensen's (1998) and Bain's (2000) earlier findings that document young children's use of CS for power, control, and dominance. Therefore, the variation in the use of sociolinguistic functions for CS reflects particular means to achieve discourse goals during peer interactions.

\section{Discussion and Conclusion}

An unexpected finding was the consistent use of Spanish (the children's native language) as the base language in both types of conversations and contexts. A possible explanation to these findings is that the children might have felt some pressure in carrying out the science activity and answering the questions, in order to report back to the adult researcher. Therefore, the children were more comfortable using Spanish to solve the science activity. Because the activity was a cognitive task, the children might have switched to their native language, Spanish, as a result of wanting to get through all the science activity questions. A similar finding was reported by Glaessner (1995), who noticed that her bilingual students used two languages strategically to engage in private speech and collaborative speech when cognitively challenged. Moreover, Benjamin (1996) also documented schoolchildren's use of their native language, Spanish, to communicate their knowledge to carry out complex academic tasks while negotiating participation in ongoing conversations. Similarly, the children in the present study used their native language (Spanish), in addition to CS, to negotiate conversational involvement while seeking explanations during the science activity, as exemplified below: 
Araceli: t: [ reading] ¿qué es lo que los im::anes hacen al compass *brújula brújula?

e: what do magnets do to a compass compass?'

Mari: $\mathrm{t}$ : um...

Araceli: t: compás?

e: compass?

Mari: t: estás segura?

e: are you sure?

Araceli: t: (you) know

Mari: $\mathrm{t}: \sim \mathrm{um}-\mathrm{huh}$

Araceli: t: do you understand one?

Mari: $\quad \mathrm{t}$ : can you use it?

Araceli: t: entiendes número uno?

e: do you understand number one?

Mari: $\mathrm{t}$ : huh?

Araceli: t: le entiendes?

e: do you get it?

Mari: $\quad$ t: yeah, it goes north

In the example above, two fifth-grade girls are switching back and forth between Spanish and English to check with each other their understanding of one of the questions during the science activity. In this particular example, the children use CS as a clarification function successfully to answer the questions on the worksheet.

In terms of the frequency patterns of CS, the 10-year-olds showed a higher frequency than the 7-year-olds of code switches in all contextssocial talk, science activity on-task talk, and science activity off-task talk. Interestingly, both age groups showed about the same percentage of code switches across contexts. In other words, context, at least in this specific situation, did not seem to affect the frequency of CS among the children. Previous research by McClure (1981) also reported that setting was a secondary factor for language choices by Mexican American children.

In sum, there was some variation in the sociolinguistic functions of code switches used with respect to the type of context. During the social talk, the most systematic function for CS among children was the topic of the conversation. An important difference found between the two age groups was the function of accommodation CS to the other speaker. In the present study, children during peer interaction seemed to be monitoring and accommodating their peers' linguistic abilities (see example above). These findings showed that older children, who have developed bilingual competence 
(including metalinguistic knowledge of two languages), were aware of their listeners' linguistic abilities and accommodated to their peers' skills. Lanza (1997) has pointed out that metalinguistic awareness can be evidenced in different ways. For the bilingual child, CS is an index of bilingual competence development. For the science activity (on task), switching to add emphasis to a statement and to clarify information given to the listener was important when a child had a question regarding the activity. Children manipulated their languages in order to make sure the other child understood what they were trying to communicate. Results from this study confirmed McClure's (1981) previous finding that using CS to clarify meaning through translation seems to be learned at quite a young age. Of particular interest in this study is the finding that CS to mark topic shift seems to be a type of code switch that is learned at an earlier age than other, more sophisticated types of code switches (e.g., turn accommodation, imitation quotation).

In conclusion, these results show that children during peer interaction use the language with which they both feel most comfortable and have greater competence. The results also indicate that those speakers with the greatest degree of bilingual communicative competence are the ones who most frequently use CS as a strategy to meet their conversational goals and to communicate with their peers. This finding suggests that a positive relationship exists between bilingual CS and language proficiency, and that "the number of instances of 'code-switching' can be interpreted to reflect the child's developing communicative competence" (Genesee, 2002, p. 190). This is an important finding that challenges the view of CS as a sign of communicative incompetence. Instead, it calls for attention from teachers, parents, and educators to draw on children's language resources (Ruiz, 1984) to help students achieve academic and communicative competence. In recent work in educational sociolinguistics, Gumperz, Cook-Gumperz, and Szymanski (1999) have identified CS as one of the skills bilingual children used during cooperative learning environments. They argue that CS is part of children's linguistic knowledge, and that it must be recognized as conveying essential information that affects their understanding of others.

Children, as they get older, seem to learn to code switch for more sophisticated purposes. One explanation could be that they become more sensitive to their peers' linguistic abilities, consequently becoming better at $\mathrm{CS}$ to accommodate their linguistic demands. That is, they know roughly the level of bilingual fluency that their friends and adults possess, and at the same time this helps them to be better communicators by taking advantage of their bilingual skills. In a recent article, Ervin-Tripp and Reyes (in press) have described this skill as part of children's developmental bilingual pragmatics. Therefore, as bilingual children's exposure to the L2 increases, their bilingual communicative skills advance and they are able to switch languages with ease, knowing when it is appropriate to mix them and when they should keep the languages separate. 
This study has attempted to explore the different patterns of CS functions Spanish-English bilingual children use during peer conversation. For future studies, it will be necessary to do a comparative analysis including other languages and children from different ages to see how the use of their native language and CS during peer interaction extends the linguistic repertoire of bilingual language learners for greater pragmatic and academic competence. These findings are particularly important for classroom teachers, because CS should be understood as a tool for cognitive development and a skill children use to achieve communicative goals. Moreover, the findings from this study indicate that CS is a complex skill children develop as part of communicative competence. Educators, teachers, and parents should not consider CS a sign of cognitive confusion, but instead an indicator of children's bilingual competence. This research should help educators of second language learners facilitate discourse practices in the classroom according to students' first language and second language linguistic skills.

\section{References}

Álvarez, A. I. (1979). Code-switching among bilingual children. Unpublished doctoral dissertation, University of Massachusetts, Amherst.

Bain, B. (2000). Toward a fuller appreciation of codeswitching. Journal of Pragmatics, 32, 1405-1411.

Bayley, R., \& Zapata, J. (1993). Prefiero Español because I'm used to it: Code-switching and language norms in south Texas. Working Papers, 02. San Antonio: University of Texas at San Antonio, Hispanic Research Center.

Benjamin, R. (1996). The functions of Spanish in the school lives of Mexicano bilingual children. Bilingual Research Journal, 20(1), 135-164.

Clyne, M. G. (1967). Transference and triggering. The Hague, Netherlands: Martinus Nijhoff.

Ervin-Tripp, S. (1964). An analysis of the interaction of language, topic \& listener. American Anthropologist, 66(6, Part 2), 86-102.

Ervin-Tripp, S. (2001). Variety, style-switching, and ideology. In P. Eckert \& J. Rickford (Eds.), Style and variation (pp. 44-56). New York: Cambridge University Press.

Ervin-Tripp, S., \& Reyes, I. (In press). From child code-switching to adult content contrast. International Journal of Bilingualism.

Escalera, E. (2002). The role of context in children's use of discourse markers. Unpublished doctoral dissertation, University of California, Berkeley.

Fantini, A. E. (1985). Language acquisition of a bilingual child: A sociolinguistic perspective. San Diego, CA: College-Hill Press. 
Fishman, J. A. (1965). Who speaks what language to whom and when? La Linguistique, 2, 67-88.

Genesee, F. (2002). Portrait of the bilingual child. In V. Cook (Ed.), Perspectives on the L2 user (pp. 170-196). Clevedon, England: Multilingual Matters.

Genesee, F., Boivin, I., \& Nicoladis, E. (1996). Talking with strangers: A study of bilingual children's communicative competence. Applied Psycholinguistics, 17, 427-442.

Genishi, C. (1976). Rules for code-switching in young Spanish-English speakers: An exploratory study of language socialization. Unpublished doctoral dissertation, University of California, Berkeley.

Glaessner, B. E. (1995). Bilingual children in school: The negotiation of language use in a first-grade classroom. Unpublished doctoral dissertation, University of Chicago.

Gumperz, J. J. (1964). Linguistic and social interaction in two communities. American Anthropologist, 66(6, Part 2), 137-154.

Gumperz, J. J. (1967). On the linguistic markers of bilingual communication. Journal of Social Issues, 23, 48-57.

Gumperz, J. J. (1973, April). The communicative competence of bilinguals: Some hypotheses and suggestions for research. Language in Society, 2(1), 143-154.

Gumperz, J. J., \& Berenz, N. (1993). Transcribing conversational exchanges. In J. A. Edwards \& M. D. Lampert (Eds.), Talking data (pp. 91-122). Hillsdale, NJ: Lawrence Erlbaum Associates.

Gumperz, J. J ., Cook-Gumperz, J., \& Szymanski, M. (1999). Collaborative practices in bilingual cooperative learning classrooms: Research Report 7. Santa Cruz, CA: Center for Research on Education, Diversity, \& Excellence.

Gumperz, J. J., \& Hernández-Chavez, E. (1975). Bilingualism, bidialectalism, and classroom interaction. In C. Cazden, V. P. John, \& D. Hymes (Eds.), Functions of language in the classroom (pp. 84-107). New York: Teachers College Press.

Halmari, H., \& Smith, W. (1994). Code-switching and register shift: Evidence from Finnish-English child bilingual conversation. Journal of Pragmatics, 21(4), 427-445.

Hymes, D. H. (1974). Foundations in sociolinguistics: An ethnographic approach. Philadelphia: University of Pennsylvania Press.

Jørgensen, J. (1998). Children's acquisition of code-switching for power wielding. In Peter Auer (Ed.), Code-switching in conversation: Language, interaction and identity (pp. 237-261). London: Routledge. 
Lanza, E. (1997). Language mixing in infant Bilingualism. New York: Oxford University Press.

McClure, E. (1981). Formal and functional aspects of the code switched discourse of bilingual children. In R. P. Duran (Ed.), Latino language and communicative behavior (pp. 69-84). Norwood, NJ: Ablex.

Poplack, S. (1980). Sometimes I'll start a sentence in English y termino en español.Linguistics, 18(7\&8), 581-618.

Reyes, I. (2001). The development of grammatical and communicative competence in bilingual Spanish speakers. Unpublished doctoral dissertation, University of California, Berkeley.

Romaine, S. (1995). Bilingualism (2nd ed.). Oxford, England: Blackwell.

Ruiz, R. (1984). Orientations in language planning. Bilingual Research Journal, 8(2), 15-34.

Saunders, F. (1975). Code switching in bilingual children. Unpublished doctoral dissertation, University of California, Santa Barbara.

Schieffelin, B., \& Ochs, E. (1986), Language socialization across cultures. Cambridge, England: Cambridge University Press.

Weinreich, U. (1953). Languages in contact. The Hague, Netherlands: Mouton.

Zentella, A. C. (1982). Code-switching and interaction among Puerto Rican children. In J. Amastae \& L. Ellas-Olivares (Eds.), Spanish in the United States: Sociolinguistic aspects (pp. 354-385). Cambridge, England: Cambridge University Press.

Zentella, A. C. (1997). Growing up bilingual. Maiden, MA: Blackwell.

\section{Acknowledgments}

Support for this research was provided by a Social Science grant by the University of California, Berkeley. I am grateful to Susan Ervin-Tripp for comments and discussion on earlier drafts of this manuscript. Please address correspondence to Iliana Reyes at Department of Language, Reading and Culture, College of Education, University of Arizona, Tucson, AZ 85721-0069. E-mail can be sent to: ireyes@email.arizona.edu

\section{Endnotes}

1. The first line, $\mathrm{t}$, is the transcript literally from the tape. Line e: is a free translation into English to give the meaning. The * indicates accent and normal prominence.

2. Pseudonyms have been used to protect children's identity.

3. For comparison purposes, proportions were computed by dividing the number of code switches by the number of speaking turns for each child to yield a measure of CS probability per turn in each context.

4. The term metalinguistic knowledge refers to the ability to reflect and think about the nature and functions of language (Lanza, 1997). 


\section{Appendix A}

\section{Science Activity Questions \\ Cuestionario de ciencias naturales}

1. ¿A que lado apunta la brújula?

Which way does the compass point?

2. What do magnets do to a compass?

¿Qué es lo que los imanes hacen a la brújula?

3. What do the magnets do to the other things?

¿Qué hacen los imanes a los otros objectos?

Find all the different things the magnets do. Encuentren todas las cosas que se pueden hacer con los imanes y los diferentes objetos.

4. Usen los imanes con la caja que contiene el polvo con hierro, y volteenlo al revés ¿Qué es lo que pasa? ¿porqué? Put a magnet on the box with iron filings and turn it upside down. What happens? Why?

5. How can you tell which objects contain iron?

¿Cómo puedes saber que objetos contienen hierro?

6. Traten de darle vuelta a la piedra "hematite" (negra/lisa) con uno de los imanes. ¿Porqué da vueltas? Try to spin the hematite with the bar magnet. Why does it spin?

7. The $\mathrm{N}$ and $\mathrm{S}$ on the magnets mean north and south. What happens when you put two norths or two souths together? How about a north and a south? La N y $\mathrm{S}$ en los imanes significan norte y sur. ¿Qué pasa cuando tratas de poner dos $N$ o dos $S$ juntas, y que pasa cuando pones la $N$ y la $S$ juntas?

8. ¿Cómo puedes saber cual es Norte o Sur en los imanes redondos? How can you tell which side of the circle magnets is north or south? 


\section{Appendix B}

\section{Transcription Notation}

\section{(from Gumperz \& Berenz, 1993)}

\begin{tabular}{|c|c|c|}
\hline Symbol & & Significance \\
\hline$*$ & & Accent; normal prominence \\
\hline$* *$ & & Extra prominence \\
\hline$\sim$ & & Fluctuating intonation over one word \\
\hline$?$ & & Rising intonation at end of intonation contour \\
\hline / & & Falling intonation at end of intonation contour \\
\hline , & & Holding intonation at end of intonation countour \\
\hline // & & Turn-final intonation \\
\hline- & & Truncation (e.g., what ti- what time is it/) \\
\hline$::$ & & Lengthened segments (e.g., wha::t) \\
\hline .. & & Pauses of less than .5 second \\
\hline ... & & Pauses greater than .5 second (unless precisely timed) \\
\hline$<3>$ & & Precise units of time (= 3 second pause) \\
\hline( & ) & Unintelligible speech \\
\hline (they) & & A good guess at an unclear word \\
\hline (“ & “) & Regularization (e.g., i'm gonna (“going to") come soon/) \\
\hline \# & \# & $\begin{array}{l}\text { Use hatchmarks when extratextual information needs to be } \\
\text { included within the text (e.g., R: did you ask E\#surname\# to } \\
\text { come?) }\end{array}$ \\
\hline[ & ] & $\begin{array}{l}\text { Nonlexical phenomena which interrupts the lexical stretch } \\
\text { (e.g., text[laugh] text/) }\end{array}$ \\
\hline$\{[$ & ]\} & $\begin{array}{l}\text { Nonlexical phenomena which overlays the lexical stretch } \\
\text { (e.g., }\{[\text { laugh }] \text { text/ }\} \text { text/) }\end{array}$ \\
\hline$=$ & & $\begin{array}{l}\text { To indicate overlap and latching of speakers' utterances } \\
\text { (e.g. L: so you understand = the requirements = } \\
\text { G: = yeah, I under }=\text { stand them } / \text { ) }\end{array}$ \\
\hline
\end{tabular}

Note. The use of uppercase letters is restricted to proper names to identify a person or place. All regular orthographic annotations have a specific meaning for this transcription notation. 